\title{
Clinical and Critical: The Lacanian Contribution to Management and Organization Studies
}

\author{
Gilles Arnaud (ESCP Europe) et Bénédicte Vidaillet (IRG, Université Paris Est Créteil)
}

\begin{abstract}
Over the past 15 years, an increasing number of researchers have become aware of what the French psychoanalyst Jacques Lacan's work can contribute to management and organization studies. The number of publications on the subject has significantly risen, at the risk of leading to some apparent heterogeneity of the topics covered and a potential distortion of the Lacanian concepts when used in management and organization studies. In this article, we aim to map this emerging field of research, bring to light the theoretical basis common to those works so as to make the Lacanian theory used to study management and organization more legible, and discuss the limitations and opportunities implied by such a Lacanian approach. We organize the published works around two main orientations, each helping to address specific issues: a clinical orientation, within organizational psycho-dynamics, and a critical orientation, related to critical management studies.
\end{abstract}

Keywords

Critical management studies, Lacan, organizational psycho-dynamics, psychoanalysis

Jacques Lacan's work began to be used for studying organizations and management at the turn of the 2000s. A number of publications by French, Belgian and English authors led the way (Arnaud, 1998, 2002, 2003a; Fleming and Spicer, 2003; Roberts, 2005; Vanheule et al., 2003; Vanheule and Verhaeghe, 2004; Vidaillet, 2007, 2008a). A more visible and structured expression of this interest in Lacan's work emerged with two workshops on Lacan at work (in 2008 and 2013), a special issue of Organization, "Jacques Lacan with organization studies" (Contu, Driver and Jones, 2010), a collective book Lacan and Organization (Cederström and Hoedemaekers, 2010), and a special issue of Organization Studies on the contribution of psychoanalysis to the organizational field (Fotaki, Long and Schwartz, 2012) that gives pride of place to Lacan's approach. Although this interest pertains to a specific field of study, it is nonetheless true that a rising number of researchers have become aware of what Lacan's work can contribute to management and organization studies [MOS]. This growing interest explains why the volume of Lacanian organizational research has significantly increased, at the risk of leading to some disconnection and apparent heterogeneity of the topics covered (Arnaud and Vanheule, 2013). This rapid expansion then creates the need for a review and classification of what is being done in this new area.

In this respect, the purpose of this paper is threefold. Firstly, we aim to review most of the publications which, in the last twenty years, have revolved around Lacan and organizations. This will enable us to identify the various areas of inquiry linking these works, so as to map this emerging field of research, without forcing it into a rigid and ostensibly orderly representation (Contu et al., 2010; Jones, 2010). 
The task here is to develop around Lacan, what has already been developed in the field of organizational psychoanalysis around Freud and the post Freudians (Carr, 2002; Carr and Gabriel, 2001). Secondly, when reviewing this fairly recent literature, we intend to show why and how Lacanian concepts may be useful in exploring various theoretical perspectives and new ways of approaching practical issues in MOS. Thirdly, we propose to organize Lacan-inspired research around two major orientations that developed in distinct academic fields and with different objectives (Butler, 2008) despite some citation overlaps between both entities: the first orientation, of a clinical nature, pertains to organizational psycho-dynamics; the second, qualified as critical, relates to critical management studies (CMS). The very existence of this second orientation has much to do with the fact that Lacan's work has been disseminated far beyond the borders of analytical circles and particularly, outside France, in the academic philosophical arena, which it has entered with no particular link to the clinical practice of psychoanalysis (Badiou and Roudinesco, 2012).

On the one hand, a clinical approach that draws upon psychoanalytic concepts and techniques has much to contribute to our understanding of organizations and the practice of management (Gabriel, 1999). The clinical paradigm is based on a few key premises (Kets de Vries, 2004): first, all human behavior, even in its most odd or deviant forms, has a rational explanation, and one must look beyond a person's irrational activities and attempt to acknowledge and decipher these forms of irrationality; second, our unconscious plays a tremendous role in determining our actions, thoughts, fantasies, hopes, and fears, which directly impact what happens in the so-called rational domain of our actions; third, our past determines who we are throughout our lives. On the other hand, 'to be engaged in critical management studies means, at the most basic level, to say that there is something wrong with management, as a practice and as a body of knowledge, and that it should be changed' (Fournier and Grey, 2000, p. 16). More fundamentally, critical analysis consists in questioning the obvious facts on which action is based or through which it is justified, in unveiling the political and ideological rationales at work in organizations (Alvesson and Willmott, 2003), and more broadly in bringing to light what may be unacceptable about them, so as to be able to propose alternatives. Within each of these orientations - clinical and critical - the Lacanian approach has helped to not only address specific questions, but also to develop an alternative to other current approaches, in order to address still existing gaps in the MOS literature. Our intention here is to reveal the specificities of each orientation, considering that they have largely developed independently of each other. We note that, in some respects, clinical and critical preoccupations are becoming so closely intertwined that they could be reviewed together. However, as we are going to show, there are still enough differences to keep them separate.

Other works have previously presented and discussed Lacan's contribution to MOS. While our article builds on those works, it differs from them in several respects: it provides a thorough review of the 
main research streams in Lacanian organizational scholarship, whereas other studies have aimed to either introduce Lacan's thought on organizations (e.g. Contu et al, 2010;. Glynos, 2010; Hoedemaekers, 2010; Jones, 2010), or to present a wider panorama by reviewing both Lacanian and non-Lacanian works (e.g. Arnaud, 2012), or on the contrary, to focus on a specific aspect, whether epistemological (e.g. Arnaud and Vanheule, 2013) or operational (e.g. Kenny, 2009). Moreover, the aim of our contribution is to provide an extensive examination of two dimensions - clinical and critical - which are often addressed in distinct publications.

In this review paper, we have primarily selected the studies in which Lacanian theory is the main reference (i.e. in which Lacan's work is used more than just occasionally or secondarily) and whose authors engage in a direct dialogue with Lacan's thought on the issues they examine. We have paid particular attention to those among Lacan-based works whose focus is clearly on organizational issues (that is to say whose purpose is not to discuss Lacan's theory as such, but its application to MOS). Among the cited references, those we chose to develop more extensively are the ones which, in our view, provide the most insightful contributions from a theoretical, methodological or practical perspective.

We will discuss the published works, grouped in two distinct sections, according to whether they pertain to a clinical or critical orientation. Within both orientations, the review is organized around accepted research topics in MOS, in order to show what clinical and critical might have to contribute. We will simultaneously present the key concepts of Lacanian psychoanalysis used by researchers, in such a way as to situate Lacan in the existing categories of the organizational field, as was recommended by Pavón-Cuéllar (2010) in the psychological field. Finally, in a concluding section, we will discuss the points of convergence and complementarity between clinically and critically oriented studies, and will examine the limitations and possible avenues of development of Lacanian organization studies by calling for both a 'critique of the clinic' and a 'clinic of the critique'.

\section{A Clinical Orientation Relating Subjectivity to Desire and Language}

Although Lacan was punctually cited early on in the administrative science literature (e.g. Kets de Vries and Miller, 1987; Morgan, 1983), the first studies on organizations and management that were primarily based on Lacanian theory refer to this clinical orientation. Thus, the field of reference is that of organizational psycho-dynamics, which has historically been heavily influenced by Freudian and, especially, Kleinian or Bionian conceptions (Arnaud, 2007; Driver, 2003; Long, 2006). These works have in common that they take into account psychical processes usually overlooked by cognitive and behaviorist models, because they occur at both emotional and unconscious levels. Typically, the topics 
addressed by the psychoanalytic approach to organizations relate to the study of leadership, work motivation, emotions, group dynamics, organizational roles, culture, and identity, or change management, among others (e.g. Arnaud, 2012; Gabriel, 1999; Kets de Vries, 1991). In this respect, psychoanalysis is used to enhance the explanatory power of MOS (Fotaki et al., 2012; Hirschhorn and Neumann, 1999), and to develop methods of intervention for increasing the level of organizational reflexivity (Gabriel and Carr, 2002).

In this context, the emergence of research based on Lacan's work has led to an important conceptual and practical reappraisal of psychoanalytically grounded organizational study and intervention whose theoretical and clinical approaches have been challenged by the Lacanian alternatives (Arnaud and Vanheule, 2013; Contu et al., 2010). This may explain the timid and limited, but interesting nature of the first forays into this new territory attempted by the scholars already engaged in organizational psycho-dynamics (Hirschhorn, 1998; Leather, 1983; Long, 1991; Schneider and Dunbar, 1992). It was not until the arrival of researchers whose works were directly anchored in the Lacanian tradition that Lacan began to be used more thoroughly and ambitiously. The value of these developments lies in their ability to generate new ways of addressing psycho-dynamic issues, insofar as Lacanian theory helps overcome the interventionist and individualistic tendencies psychoanalysis is often accused of (Nobus, 2000), to provide organizational researchers with a model for conceptualizing from the outset the connections between subjectivity, language and social structures (Fink, 1995; Parker, 2011).

\section{Organizational Dynamics and Work Relations: The Imaginary Vs Symbolic Dimension of the Organization}

For a long time already, socio-analysis had drawn attention to the influence of unconscious fantasies and defense mechanisms in organizational life (Pratt and Crosina, 2016). It was then postulated that the actions undertaken by members of an organization were mostly determined by collective anxieties and underlying imaginary scenarios connecting its members with one another and sometimes leading them to repeat bad decisions or block organizational processes (Kets de Vries and Miller, 1984). Note that according to non-Lacanian psychoanalytic tradition, imaginary is an equivalent for fantasmatic. By referring to Lacan's distinction between the Imaginary and the Symbolic and redefining both registers, some Lacanian organizational works (e.g. Arnaud, 2002, 2003b; Vanheule et al., 2003; Driver, 2005, 2006, 2008; Vidaillet, 2007) propose to examine the symbolic dimension, and in particular language, which structures and governs the relation of the subject to the organization under an imaginary cover.

Lacan discusses the roots of the Imaginary and the structuring function of the Symbolic in his theory of the mirror stage, when the child anticipates the unity and mastery of her body by identifying herself 
as equivalent with her image (Lacan, 1949/2006). As a result of this self-identification - as identification with the image of an alter ego - a confusion is always introduced between the ego and the other, whose otherness tends to fade in inter-subjective relations. This is why the Imaginary is the register of illusion and lure (Lacan, 1954-55 / 1988). But, regarding the mirror experience, Lacan also attaches great importance to the presence of a third party (the mother), who witnesses the discovery the child makes and confirms that it is indeed his/her reflection that $\mathrm{s} /$ he is seeing, by naming the image that appears in the mirror. This authentication by an other then allows for a detachment from the mirror image and an attachment to the Symbolic. This is why the imaginary organization is conditioned, from the outset, by the representative of what Lacan subsequently called the 'Big Other'. This Other (with a capital O) is defined as the symbolic locus in which the subject's speech is constituted. The word 'Other' does indeed convey the idea of radical otherness, that of a truth which is irreducibly external, but also and paradoxically intimate - 'extimate' as Lacan puts it (Lacan, 195960/1992, p. 129) - in that it defines a place in the constitution of the subject, of which the unconscious is the logical operator; hence the Lacanian aphorism that 'the unconscious is the discourse of the Other'. This discourse will express desires emanating from anything/anyone that serves as Big Other, and which the subject has to recognize. Thus, 'desire is the desire of the Other'. In contrast, though, the Imaginary, which seemingly attaches meaning to human behaviors, supports, or even attempts to respond to this opaque desire, while concealing the fact that it always comes from the Other. Through privileged signifiers that 'insist' because they have a particular unconscious value, it is, therefore, the Symbolic that does prevail over the Imaginary, conditioning the discourse, actions and fate of the subjects, unbeknown to them.

This change in perspective then draws the attention of Lacanian researchers to the literality of organizational discourses in relation to which individuals position themselves, and which determines them subjectively, by assigning them to different places (for example, head, expert, successor, usurper, etc.) (Arnaud, 2002; De Swarte, 2005; Guinchard, 1998). The Symbolic then appears to be what conditions organizational functioning: either by giving the individuals the opportunity to subjectivize their place to construct themselves as 'subjects of the organization' (Driver, 2006); or on the contrary, by confining them to an exacting place that totally 'forces' them and leads them into alienating or pathological forms of subjectivation (Arnaud, 2002). Thus, Lacanian concepts such as the Symbolic, the signifier or the Other can be used productively in order to better understand how organizations function and become dysfunctional (Driver, 2005; Kenny, 2009). Thus, Lacanian researchers concentrate on identifying the privileged signifiers that circulate in an organization to identify the hold the organizational Other has on its members (Naulleau, 2013); examples of this are provided by Hoedemaekers and Keegan (2010) with the signifier 'performance', or by De Swarte (2005) and Vidaillet $(2013 b, 2016)$ with the signifier 'evaluation'. 
Some of these key signifiers may be contingent upon the particular history of a given organization. A telling example of this is given by Arnaud (2002) who reports the case of a consultant, Françoise, who proves incapable of canvassing big prospective clients because of a compulsive attachment to 'small clients.' He shows that this fixation does not originate in the imaginary register, that is to say in relation to what the image of the small client might evoke for her (for example, better known or more loyal clients), but must be analyzed as being linked to the insistence of the Symbolic: Françoise is in fact bound by an unconscious debt inherited from the former head of the company, Dominique, who had made her her disciple. Analyzing this debt, which is perpetuated in displacements of inherited signifiers (such as the slippage from the signifier 'small client' to the signifier 'small clan', designating the idealized duo she and Dominique formed) then helps to understand why Françoise remains caught in the desire of the Other, embodied here by Dominique.

Thus, the line of analysis described above draws attention to the effects of a symbolic excess, or at least of a symbolic dimension, whose presence produces symptoms. Other studies, on the contrary, attract attention to work environments in which the symbolic dimension disappears in favor of the Imaginary, as in post-bureaucratic organizations in which the management control logics no longer involve written codification but cultural and identity processes (Styhre, 2008), or fades to the point of seeming singularly absent - for example in a now-deregulated financial sector with "limitless" potentialities (Arnaud, 2003b). This would appear to produce a new series of symptoms wherein the subjects experience an 'unbearable lightness of being', in which anxiety is replaced with subjective disarray and a feeling of not existing, when the Other is unreliable or missing in one way or another. Examples of this are given by Owens (2010) - drawing from her clinical independent practice - or by Vidaillet and Gamot (2015) in their study of an industrial plant - a subsidiary of a multinational corporation - that is constantly under threat of closure, and in which no one knows who the actual decision makers are.

Finally, the distinction between the Imaginary and the Symbolic is key when analyzing emotions in the workplace (Kenny, 2012). Thus, Lacanian theory is particularly useful for studying envy, as it draws attention to the concept of gaze, through which the subject experience itself as being caught in the specular image. Indeed, this concept also relates to the theory of the mirror stage, according to which the child's encounter with the mirror makes him/her realize that $\mathrm{s} / \mathrm{he}$, also, can be a specular object. In that perspective, envy at work does not merely involve an envious subject and an envied subject, and a possible object of envy between the two. It also puts into play the organizational Other whose gaze, the envious one imagines, is captured by the envied (Vidaillet, 2007, 2008b). Such a conception therefore helps identify the triangular configurations in which the subject is facing another, who is almost similar to itself, but who possesses something different (difference in performance, different bonuses, etc.) and is for this reason supposed to capture the gaze of the organizational Other 
(Vidaillet, 2008a). This conception, unlike the dominant Kleinian perspective (Stein, 2000), helps us better understand how some management systems are likely to minimize the development of envy, while on the contrary, others instigate it, depending on whether or not they introduce a symbolic dimension to prevent the subject from remaining trapped in the imaginary dimension (Vidaillet, 2016).

\section{Motivation, Organizational Commitment and Professional Identity: Lack at the Center of Desire and Subjectivity in the Workplace}

The Lacanian approach defines the subject as a highly specific concept, which is quite distinct from that of the human being in its various psychological, sociological or philosophical definitions (PavónCuéllar and Parker, 2014). What it is, indeed, is a 'subject of the unconscious', i.e. one that is manufactured and 'castrated' by language (Lacan, 1955-56/1993). Indeed, according to Lacan, access to language forces the subjects to constantly articulate themselves through a symbolic structure that disconnects them from themselves and from the world. If a subject comes to exist as a result of entering 'the order of the signifier', desire, then, is what drives this subject into the 'snares of the signifier', a subject in relentless pursuit - through speech - of a completeness that is forever lost: Desire therefore addresses the lack. Consequently, the subject, according to Lacan, should be conceived not as a substantial entity, but as the witness-function of this inevitable symbolic distance introduced in its relation to the world and itself, which engenders desire (Lacan, 1960/2006).

This Lacanian conception of the subject has opened up very interesting perspectives on subjectivity at work. First of all, it has led to consider one's relation to work as a desiring process. Thus, Arnaud and Guinchard (2008) theorize the 'desire for work', which makes it possible to place work in the same category as love in that they both embody the two modes of realization of desire. Work then establishes itself as an internal 'reality' for each subject, who refers to it as 'my job' and is attached to it by an unconscious and conflictual dynamic: hence the place it occupies in our lives, and the persistence of the energy that leads us to get up in the morning to 'go to work' (Arnaud, 2013). This conception shows that the question of motivation neglects some essential aspects. If there is indeed a desire for work, then it constructs itself structurally on lack and cannot be satisfied. Thus work can even be envisaged as needing to be partly unsatisfying in order to foster desire. The question is therefore no longer about how to have satisfied employees, but to figure out how to create a space for elaborating this desire for work in organizations (Guinchard and Arnaud, 2011).

This perspective also enables Lacanian authors to develop new ways of addressing work-related pathologies such as stress and burnout. For example, Vanheule et al. (2003) and Vanheule and Verhaeghe (2004) show that special educators who suffer from burnout are those who identify the most with their professional role, in a process of imaginary collage that prevents them from distancing 
themselves from that role, but also from their co-workers, managers and clients. These imaginary identifications constantly fuel the subjects' demands for recognition and for the satisfaction they expect from exercising their job, and consequently prevent them from identifying and understanding the difficulties, limitations and impossibilities inherent both to their activity and to their symbolic place within the organization. By contrast, those who perform their job mostly on the basis of the symbolic determinations that characterize their position (whereby they take into account the structural context of the events with which they are confronted) are less concerned about what they project onto others, and seem better equipped to face the contradictory dimensions of their work, while their ability to recognize the dimension of lack enables them to better preserve their long term desire for work (Arnaud and Vanheule, 2007).

To characterize what differentiates these two opposite configurations, Lacan-inspired studies also use the concept of jouissance, another one of Lacan's major inventions, which refers to a particular satisfaction derived from obtaining a desired object as beyond the pleasure principle. It originates in the perceived plenitude of the mother/child relation; a feeling of plenitude, which language acquisition will permanently deprive the child of by differentiating the infant from the Other and by establishing the latter as the infant's object of desire: desire to restore this mythical bliss through substitutes for the first lost object, substitutes which can only be partially satisfactory (Lacan, 1959-60 / 1992). However, the archaic maternal Other leaves a psychic trace of this absolute jouissance, which fuels an injunction pushing the subject to abandon the limitations of desire in a deadly subordination to the Other. This subordination is a cause of suffering, but it never entirely extinguishes the relentless quest for jouissance (Lacan, 1963/2006). This is also where the fundamental difference between pleasure, which can be satisfied and limited, and jouissance lies (Lacan, 1969-70 / 2007). In the last part of his teaching, Lacan came to make a distinction between several jouissances (see Jadin and Ritter, 2012). In particular, he used the term 'phallic jouissance' for the jouissance that is accessible to the subject due to castration - a jouissance which is therefore possible but irreducibly barred, marked by a lack. He also identifies a jouissance that is outside language and not struck by castration, which he refers to as 'jouissance of the Other' (and more specifically of the lack in the Other) and describes as being unlimited (Lacan, 1972-73/1999).

Using fieldwork conducted in two prestigious restaurants and a fire station, Bicknell and Liefooghe (2010) explore the relationship between stress and jouissance. They point out that the cook or the firefighter, under constant pressure to perform, are enjoying their suffering. In Lacanian terms, the subjects are trying to sort out what the Other wants from them (through the clients or users' demands), so as to realize this desire. But this attempt is bound to fail, and yet, it is precisely the failure of this fantasy that brings passion into their work and sustains their jouissance. The influence of this internalized Other on jouissance may also manifest itself through organizational values that embody 
impossible objects of desire; objects which the employees are willing to work tirelessly to obtain. Such is the case of professionalism, as an unattainable ideal, which they constantly strive to attain (Kosmala and Herrbach 2006) or of employability, in relation to which they will inevitably prove 'never employable enough' (Cremin, 2010). The Lacanian approach makes it possible to not limit oneself to denouncing problematic issues, but to also to envisage possible ways out (Hoedemaekers, 2010). Indeed, narrating one's stress provides an opportunity to express unconscious desires, prompting the subjects to break from the alienating conscious selves that they have constructed (eg stress-fit persons who can handle anything) by experiencing how their difficulties can act as a creative confrontation with their lack of being (Driver, 2014; Vanheule et al., 2003).

More generally, this conception of lack as a productive flaw proves to be key in understanding professional identities, which the Lacanian perspective helps to analyze in a new light. Indeed, the identity literature, which traditionally conceives identity as coherent or fragmented, tends to essentialize it (Driver, 2015). But, when seen from a Lacanian perspective, identity in the workplace is problematic primarily because it is structured around a fundamental lack, which is precisely what is missing from the discourse, in which identity is articulated as a definable entity (Driver 2009c). This lack appears as that of an essence, in the sense, for example, of 'being professional' (Kosmala, 2013) or 'being an ideal employee' (Hoedemaekers, 2010). The above mentioned Lacanian concepts (lack, imaginary identification, jouissance) then not only help to explain why the imaginary register proves so powerful, in that it promises wholeness and jouissance to the subjects, who dream themselves as non-lacking (Dashtipour, 2009; Hoedemaekers, 2009; Roberts, 2005), but they also make it possible to explore this failure and the liberating and empowering struggles that may accompany it when lack is recognized and articulated, rather than covered up (Driver, 2008, 2013, 2017). They then draw attention to the faltering of identity, which manifests itself in slips, contradictions and interruptions in the discourse of the subjects and offers the possibility of identifying the iterative dynamic of breakdown, dis-identification and re-identification operating in identity work (Driver, 2009a; Hoedemaekers, 2010; Kosmala and Herrbach, 2006).

\section{Organizational Consultation, Coaching and Management Training: Ethic of the Signifier and Symbolic Transference as Levers for Intervention}

The various developments outlined above have practical consequences on possible intervention and management training methods of Lacanian inspiration (Boxer and Palmer, 1994; Bracher, 1996). Indeed, they draw the implications of self, work and organization defined primarily through the dimension of lack, and a subject whose subjectivity and desire must be respected and handled with care (Arnaud and Vanheule, 2007; Driver, 2009b). Thus, the above mentioned research studies on identity emphasize the importance of favoring the failure of the imaginary identity in which they 
alienate themselves and to connect to the lack that marks identity discourse, and thus develop the liberating ability to re-signify themselves (Driver, 2009a; Hoedemaekers, 2010). They then call for the creation of productive discursive spaces in the workplace, through which this lack can be acknowledged and even amplified, and which will enable working subjects to experience themselves as desiring subjects (Driver, 2008, 2009c, 2015; Harding, 2007). However, those studies do not specify what form those spaces should take in practice, nor how these could be supervised to contain the anxiety experienced by subjects in the face of the 'nothingness' of self, work and organization, when their imaginary constructions are disrupted (Arnaud and Vanheule, 2007).

Other clinical works, therefore, had to be conducted to develop and implement Lacan-inspired intervention approaches (Kenny, 2009). Those studies refer to Lacan's principles on the direction of analytic treatment (1955/2006); principles for use by psychoanalysts and then by consultants, coaches or trainers. These indications can be subsumed under the expression 'ethic of the signifier' coined by Žižek (1991: 80). Indeed, the Lacanian clinic draws from Freud's recommendation for psychoanalysts to approach each new case as if they knew nothing, because knowledge is on the side of the signifiers repressed by the symptom of the analysand according to an ever idiosyncratic particularity. Thus, for Lacan, one key principle is that a signifier only acts as a signifier when it is produced hic et nunc. The aim of psychoanalysis is therefore to lead the subject, not to find some hidden meaning (as other postFreudian approaches recommend doing), but to produce a new enunciation. This process should, therefore, in no way be limited to merely conveying information or decoding meaning, without the subject engaging itself in it - which Lacan refers to as 'empty speech' - but must also transform the relation between signifiers - which Lacan calls 'full speech', so as to make the subject of the unconscious and the Symbolic connect differently (Lacan, 1956/2006).

This particular ethic does not, however, only apply to psychoanalysis in private practice: it can be exported to all discursive places, including in organizational settings; This has led some researchers to further develop Lacan's analytical technique for adapting executive coaching, consulting and management training to subjective as well as collective needs, and to conduct experiments in order to test these intervention mechanisms (Arnaud, 1998, 2002, 2003a; Driver, 2010; Guinchard and Arnaud, 2011; Vanheule and Arnaud, 2016; Vanheule and Verhaeghe, 2004; Vidaillet and Vignon, 2010). The latter are intended to enable the working subjects to produce 'full speech', which alone has the capacity to bring about change (Driver, 2005; Vidaillet, 2007). For example, among dual-system students, by organizing training programs in which they are encouraged to recognize and work through the existence of a 'reality shock' that is bound to occur, giving them the opportunity to uncover the imaginary identifications at the root of both their expectations and their disappointment, and to explore the symbolic dimensions that determine their relation to work, with the purpose of discovering and opening up the range of possible actions they can take (Vidaillet and Vignon, 2010). 
Beyond the content of discourse, what matters is the effects of the deployment of speech; indeed, it is through speech, in the interlocution, that change can occur in the relation between the subjects and certain signifiers essential to their professional identity, and thus enable them to recover some freedom (Arnaud, 2002; Driver, 2009b). Indeed, in so far as it recommends concentrating on the signifiers, the Lacanian approach opens up to problem-solving methods based on linguistic mechanisms (Nobus and Quinn, 2005). Thus, according to another key principle set out by Lacan, the analyst must absolutely refrain from interpreting what the analysand says (unlike what a non-Lacanian approach to treatment recommends), but should strictly focus on exploiting the equivocity of the signifiers in order to bring about new meaning. This is what Arnaud (2002) does in the above-mentioned case of Françoise, by identifying, during a coaching interview, the signifying substitution between 'small clan' and 'small client'.

Here, the efficiency of the intervention lies in the establishment of a transference between the coachee and the coach (Arnaud, 1998, 2003a; Vanheule and Arnaud, 2016). Indeed, for Lacan (1954-55/1988), the crux of transference does not reside in the traditional notion that subjects project their previously learned relational expectations and feelings onto the analyst because they see the latter as a figure from their past. We are referring here to the imaginary dimension of transference. Instead, what is determinant in transference is that, due to the interplay between a signifier articulated by the analyst and a signifier articulated by the analysand, an expectation emerges in the latter, which is linked to the symbolic dimension of transference (Lacan, 1953-54/1988) : the analyst, by the mere fact that s/he is spoken to, represents, for the analysand, a figure of the Other, that is to say, a subject supposed to have unconscious knowledge, and whom Lacan calls 'subject supposed to know' (Lacan, 1967/2001). This has strong implications in terms of how transference is to be dealt with. While non-Lacanian analysts often interpret transference directly, Lacanian analysts usually do not, because they cannot hold themselves in a meta-position. All attention, by contrast, has to go to the play between signifiers (Fink, 2007).

Applied to Lacanian-oriented coaching, this means that a precondition for intervention is that the coachee should not be a mere consumer who passively awaits the coach's solution (Arnaud, 1998). If such openness is present, or grows during preliminary meetings, the main task of the Lacanian coach consists of echoing outstanding signifiers and inviting clients to explore contexts in which these signifiers might have played a role (Arnaud, 2002). A Lacanian coach - unlike one who uses other psycho-dynamic approaches (that readily refer to the company as a maternal imago, to the managing director as the father figure, to the existence of collective unconscious fantasies of the same type in all organizations, etc.) - will, therefore, avoid imposing a preconceived meaning - however relevant it might be - which would run the risk of alienating the subject (Arnaud, 2003a). This approach is based on a philosophy of intervention that distances itself from the practices of those whom Lacan calls 
'engineers of the soul' (Lacan, 1955/2006, p. 293), which he strongly criticizes, and who claim to use their knowledge of psychical processes to influence behaviors, position themselves as experts or promise individuals to help them fit in better and be more efficient. In a Lacanian intervention, change is only envisioned by allowing the subject to transform its subjective position. But even though the organization itself is not an initial target, such subjective transformation also has an organizational impact in terms of a release of creation and engagement potentials (Vanheule and Arnaud, 2016).

\section{A Critical Approach based on a Negative Ontology}

A second line of Lacan-inspired studies in the field of management and organization refers to critical analysis. This critical dimension is a very interesting characteristic of the Lacanian approach to organizations, which makes it possible to distinguish it from other psychoanalytical approaches that previously dominated the field while situating it entirely within the Freudian paradigm in terms of the potential of psychoanalysis for approaching society, culture and science from a critical perspective (Bendl, 2008; Fotaki, 2011; Fotaki and Harding, 2013; Wozniak, 2010). As Parker notes (1997), this critical and progressive potential of psychoanalysis is not developed in all psychoanalytic schools, some even finding, in psychoanalysis, support for particularly conservative political positions.

Within critical management studies, Lacanian theory is used as a basis for discussing and calling into question the functioning of organizations in an ultra-liberal capitalistic society. Lacan's work is generally suggested as an alternative to that of other defenders of the French theory - notably Foucault - or of the Frankfurt school. However, it is mainly as an alternative to Foucault that it is used, in practice, by critical researchers in the field of MOS; researchers often inspired by the constructive use that thinkers such as philosopher Slavoj Žižek or political scientists Ernesto Laclau and Chantal Mouffe make of Lacan's work.

\section{Organizational Discourse Analysis: Taking the Real into account}

An essential aspect of Lacanian theory, used by researchers in critical management studies, is related to how Lacan defines discourse and in particular how he links it to the concept of the Real. Their works is, to some extent, related to approaches which, in line with the 'linguistic turn' that occurred in social science (Alvesson and Karreman 2000, 2011), examine organizations through the lens of discourse, and which have developed under the generic term of 'organizational discourse analysis' (Grant et al., 2004). Their generic hypothesis is that discourse constructs reality, which radically challenges the view according to which language 'simply' reflects reality (Ashcraft et al., 2009; Hardy et al., 2005; Mumby and Clair, 1997; Westwood and Linstead, 2001). Researchers in critical 
management studies (CMS) have built on these approaches to examine a wide range of phenomena including, for example, the discursive processes of legitimization or production of the ideologies that prevail in the field of globalization (Spicer and Fleming, 2007), in cases of organizational restructuring or shutdowns (Erkama and Vaara, 2010; Vaara and Tienari, 2008; Vaara et al., 2003), in strategy (Vaara et al, 2010), in organizational change (Thomas et al, 2011) or human resource management (Harley and Hardy, 2004). Many of these works, which examine the constructive effects of large-scale discourses (Alvesson and Karreman, 2011), are based on Foucault' ideas according to which, discourses are conceived as bodies of knowledge, and therefore are expressions of power / knowledgerelations, 'that systematically form the object of what they speak' (Foucault, 1975/1977: 49).

These approaches have been subject to much criticism, related in particular to the fact that their strong constructivist assumptions cannot capture structural dimensions of organizations and limit the account of agency, or to their giving language excessive weight, without understanding how it articulates with materiality (Alvesson and Kärreman, 2011; Pavón-Cuéllar and Parker, 2014). These criticisms refer to the 'critical realist turn' that arose in reaction to a social constructionist ontology and postmodern epistemologies. It is in the context of this call for 'critical realism', 'paradigm focused on explanations of the underlying 'generative mechanisms or structure', which shape corporate agency and the social relations that it reproduces and transforms' (Reed, 2005: 1623) that must be understood the use of the Lacanian conception of language. What is key here is to take seriously the invitation to 'get real' (Reed, 2004) about organization discourse analysis (Cederström and Spicer, 2014; Contu and Willmott, 2005).

This is the approach adopted by the researchers whose work is inspired by what - based in particular on the theory of social hegemony developed in political science by Laclau and Mouffe (1985) and on that developed by Žižek - has variously been called 'new theories of discourse' (Torfing, 1999), 'the Lacanian Left' (Stavrakakis, 2007), 'the Essex School' (Howarth et al., 2000), or 'postfoundationalism' (Cederström and Spicer, 2014; Marchart, 2007). The way in which Lacan defines the Real and articulates it to the question of language is central here. While Lacan considers that "what we call social reality is discursively constituted in language' (Lacan 1964/1998: 17), he also argues that, at the very center of any reality, there is an element that 'resists being symbolized absolutely' (Lacan, 1953-54 / 1988: 66) and which he defines as the Real. The Real refers first and foremost to a fundamental impossibility: it is what is impossible to imagine, represent, or integrate, and, in this regard, has to do with trauma. But it is also the direct result of any attempt at symbolization, because the latter systematically produces a residue, a leftover, due to the impossibility for the signifiers to attain a definite signification. The Real is, therefore, indissociable from language and refers to both an impossibility and a failure but also an excess, a left-over in the Symbolic. 
The Lacanian ontology, by highlighting the importance of the traumatic encounter with the Real, is a negative ontology, whose implications must be specified when reflecting on the social world, and in particular, on organizations (Contu et al., 2010). While critical discourse analysis proposes to uncover the 'underlying generative structures', what is suggested here is to 'confront the negativity, gaps, absences or 'lack' that discourses are structured around' (Cederström and Spicer, 2014: 186 ). It is around this negativity, which can be identified through the ambiguities, tensions or slips within a discourse (Glynos and Howarth, 2007; Parker and Pavón-Cuéllar, 2014) that 'the social' and 'the organization' are reproduced (Contu and Willmott, 2005). Jones and Spicer (2005) use this theoretical angle to analyze the impossibility of finding a stable definition of the entrepreneur, as evidenced by the abundant literature on the subject. A commonsensical interpretation would be to attribute this impossibility to the very characteristics of the object of study or to the failings of earlier researchers: our attempts to know the entrepreneur can probably only be provisional, since this function, the data and the methods used to collect them are constantly changing. However, 'these accounts assume that ontologically, there is a real and positive figure behind these provisional and ongoing iterations' (Cederström and Spicer, 2014: 188). But these repeated failures to define 'what an entrepreneur is' may not actually be failures in that they bring to light a deeper truth: : 'that 'the entrepreneur' is an empty signifier, an open space or 'lack'(...); the entrepreneur is indefinable, and necessarily so; the entrepreneur is an 'absent centre' (Jones and Spicer, 2005: 235-6). In this context, the search for 'the entrepreneur' must remain impossible for ontological reasons. The key point in this example is that discourse operates around an unsymbolizable element, that denotes the Real. But it is certainly this aspect, this lack of content (rather than a content, in itself positive, rich and complex, which would have to be discovered) that contributes to producing an endless flow of discourse. This reasoning can be applied to other popular topics in the field of management, such as 'quality', 'trust' or 'leadership'

Another very relevant Lacanian concept here is that of 'point de capiton' (Lacan, 1955-56 / 1993), interchangeably translated as 'anchoring point' and 'quilting point', but whose literal meaning 'upholstery button '- designates specific signifiers, which, in a discourse, serve, like a button tie, to tie together, at one point, the chain of signifieds and the chain of signifiers. Thus, the anchoring point has the particularity of pinning together a set of signifiers that would otherwise remain scattered, hence keeping them connected and allowing them to make sense retrospectively. Laclau and Mouffe (1985) refer to this concept using the term 'nodal point' or 'empty signifier', while Žižek (1989) uses the term 'master signifier'. Thus, in the field of management and organizations, some signifiers have a particular purpose in the discourse: 'performance' (Hoedemaekers and Keegan, 2010), 'learning' or 'flexibility' (Cederström and Spicer, 2014), for example.

Other researchers in the field of critical organization studies have also concentrated on the implications of the Lacanian Real and its associated negative ontology. Thus, some have analyzed the 
experience of the Real resulting from a symbolic death - which itself is the consequence of being stripped of a status or position - as an opportunity to seriously resist the injunctions of an organization (Contu, 2008; De Cock and Böhm 2007). According to Cremin (2007) the appeal of a gap year, so popular among students in the UK, lies in the fact that it offers a moment of excess or contingency, of traumatic encounter with the Real. The disruptive potential of trauma also makes of the gap year a point for re-imagining the subject for the labor market. As for Johnsen and Gudmand-Høyer (2010), they draw the consequences, from an ethical perspective, of an ontology that places lack, fragility or incoherence, and more generally what Jacques Lacan has termed 'practical anti-humanism', at the heart of the subject (Žižek, 2006: 46). On that basis, they contest and offer an alternative to the traditional critical perspective on HRM inspired by Foucault (Grey, 1994; Townley, 1993, 1994) who opposes the supposed inhumanity of the managerial prescription to the supposed humanity of the subjects of HRM, configured as manageable objects of knowledge by Human Resource practices.

\section{Alienation, Power and Resistance: Affect and Fantasy at the Heart of Political, Social and Organizational Life}

The negative ontology and the importance of the Real put forward by the Lacanian perspective have also led to a stimulating reflection on the issues of power, ideological adherence, submission and resistance in organizations, which had, for a long time, been the concern of CMS - including, again, through Foucault. In this latter conception, specific discourses shape the subjectivities and regulate the subjects' relation to power (Foucault, 1977-1978 / 2008) and, symmetrically, the potential resistance of each subject resides in its ability to forge new discourses and to transform, undermine or oppose the dominant discourses (Foucault, 1976/1979). However, those theories, by reducing subjectivity to a mere linguistic structure, do not help understand the subtlety of the psychic and affective processes involved in these mechanisms (Cederström and Spicer, 2014; Glynos 2010; Glynos and Stavrakakis, 2008; Roberts, 2005); they do not provide an understanding of a fact that is nonetheless essential: discourses may generate strong affective and emotional attachment.

On the contrary, of key interest in the works based on Lacanian theory is the fact that they highlight the affective and unconscious mechanisms that shape political, social and organizational life. In this perspective, the Real is not only that which 'resists symbolization absolutely', as we explained above; it is also an 'affective force' (Cederström and Spicer, 2014) that contributes to provoking intense emotional reactions. It is all the more necessary to insist upon the Lacanian conceptualization of affects, in relation to discourses and the Real, in that the risk does exist of incorrectly assuming that Lacan's theory, with its focus on the signifier, sets aside the issue of affectivity (Shepherdson, 2008). Certain discourses provoke a libidinal investment and a passionate attachment (Laclau, 2004; Stavrakakis, 2008), thus showing that discourse and affect are consubstantial. This affective dimension 
of discourse, which is fundamental in the attachment processes by which power structures persist, occurs not only in individual subjects, but also in groups and even in whole societies. For example, Scriver and Kenny (2012) argue that it is through the discursive arrangement of signifiers already imbued with affective meaning, such as opportunity, success and economic development, that the Irish government was able to maintain political power despite its loss of legitimacy against the backdrop of the crisis.

A key concept used in those works is that of fantasy, such as it is defined by Lacan. Different psychoanalytical schools define fantasy as a narrative structure that largely determines how the subject relates to the world. While Freud defines it as an imaginary scenario that allows the subject to fulfill an unconscious desire in a hallucinatory manner, Lacan is interested in the 'logic of fantasy'. According to him, one of the key functions of fantasy is to veil the lack constituted by the failure of symbolization (i.e. to conceal the lack in the Other) in order to sustain the illusion of wholeness and to prevent us from encountering the too terrifying Real that must be avoided at all cost. This generic function of fantasy has different effects in collective life. Some Lacanian researchers place fantasy at the heart of the production of social and political life and the engagement of the subject herein (Fotaki, 2009, 2010; Fotaki et al, 2010; Glynos and Stavrakakis, 2008; McSwite 1997; Stavrakakis, 2007, 2008). Considering 'policy-making as a socio-psychological process, originating in the imaginary identifications of the subject, which are enacted in the social arena' (Fotaki, 2010: 713), they give fantasy the key role of a stimulant of various social and political endeavors, of an enabler of social projects. While the subjects are caught in ceaseless efforts to make sense of their own wholeness, they draw on available socio-symbolic means to attach themselves to various ideas and projects - which are fantasmatic constructions - to both fill up and to deflect this sense of a fundamental loss.

As a fantasy gradually proves itself unable to recover the lost object of the Imaginary, new fantasies develop and are placed at the center of the political, social or organizational life. Thus, in former socialist countries, the empty space left by the demised socialist utopia needed to be filled out immediately by another fantasy - the inevitability of the market and liberal democracy - to avoid an encounter with nothingness, that is to say, with the Lacanian Real. Through this process, the symbolic order is maintained and modified through continuous interactions with the citizens' imaginary expectations (Fotaki, 2009). Finally, this conception of fantasy is highly relevant to addressing the role of failure in collective life. Firstly, the fact that it is inherently impossible for a fantasy to be realized may explain why some ideas persist, despite the fact that the failure of their implementation has been abundantly documented. Secondly, and as Fotaki (2010: 713) has noted: 'Failure is not necessarily seen as an adverse outcome, but rather as an opportunity to rethink the ideas of purposefulness and teleology in the context of organizations and social endeavors more generally. The Lacanian perspective introduces the productive element held in the recognition of the inevitability of failure, by 
unveiling the imaginary nature of striving for idealistic policies and the liberating potential of accepting loss.'

Beyond its central role in the production of political, social and organizational life, several researchers have paid particular attention to the processes through which fantasy could lead individuals to ideologically adhering to some discourses (Stavrakakis, 2007, 2008, 2010), favoring continuity and status quo (Glynos 2008, 2010, 2011), or blocking the capacity for collective resistance (Lok and Willmott 2014). Some discourses inherently have more 'sticking power' than others, because the fantasy they are linked to promises, better than others, to mask the loss and attain a form of completeness: thus, the fantasy of freedom (of choice), or the fantasy of control over the uncontrollable (Fotaki, 2010). But that's not all. Fantasy rests on the imaginary promise of recapturing lost enjoyment, and also on a key element: the obstacle that explains the loss of enjoyment (Žižek, 2009). This obstacle, which manifests itself in the form of a ban or a threat, converts the impossibility into a 'major challenge', thus leaving the impression that it can be overcome. This serves to underline another essential aspect of fantasy: its transgressive appearance. The subjects secure themselves some extra enjoyment by transgressing the ideals they officially claim to uphold, for example by eliminating the obstacle through unlawful means (Glynos, 2010). To function properly, fantasy must therefore, beyond its various forms, include both an ideal, an obstacle to the realization of this ideal, and a specific enjoyment linked to the transgression of the ideal.

Applied to MOS, such a conception helps understand why some discourses 'work' better than others. Thus, the credibility of the discourse on 'corporate social responsibility' - which involves negotiating and reaching a collective and 'reasonable' compromise that eventually results in an agreement between all stakeholders - is based on the fantasy that enjoyment is simply deferred and what one loses now will be recovered later (Vidaillet, 2013a).

Fotaki (2009) draws on the transgressive dimension of fantasy to explain why the fantasy of 'free health care' in Russia survives, precisely through the existence of informal payments which, by transgressing the official rule, constitutes, not an aberration, but a necessary precondition, to enable the functioning and maintenance of this system: official rules are not sufficient and have to be supplemented by the unwritten law of fantasy. The concept of fantasy, as it is defined above, also serves to reinterpret certain seemingly subversive behaviors, by showing how they can, on the contrary, help stabilize practices of oppression and prevent any effective change (Contu 2008; Contu and Willmott 2006; Fleming 2010; Fleming and Spicer 2003). A very good example thereof is furnished by Contu and Willmott (2006), who re-analyze a study conducted by Julian Orr on a number of Xerox-employed technicians. The latter are required to scrupulously respect repair instructions and procedures (an ideal of service), but actually often transgress them, demonstrating an inventiveness 
and original know-how they are proud of. Transgression ultimately only serves to reinforce their submission to this ideal, because they derive extra enjoyment from this transgression (pride arising from their being able to overcome, through forbidden means, the obstacles that prevented them from realizing this ideal). This is what Contu (2008) called 'decaffeinated resistance': it has the appearance of resistance, but is totally void of any real subversive power.

Another concept borrowed from psychoanalysis and reused in the field of organizations to analyze subtle forms of coercion is that of fetishism, in the sense given to it by Lacan, following Freud (Böhm and Batta, 2010). Fetishism has its roots in the disavowal by the subject of the traumatic reality of maternal castration, which the subject attempts to mask with a substitute object. Octave Mannoni, a student of Lacan's, summarizes this with a phrase that perfectly captures the fundamental ambivalence of the fetishist: 'I know very well, but all the same'. Disavowal serves here to sustain both the belief and knowledge of this belief - knowledge which logically contradicts the belief. Thus, disavowal constitutes the act of ideological adherence par excellence.

Žižek (1989) insists that the invitation to take an openly critical stance towards, and distance oneself from certain beliefs precisely constitutes the contemporary manner in which adherence to these beliefs is sustained. This attitude of detachment, of 'false dis-identification' - that which the 'return' to Eastern wisdom or to Zen Buddhism, for example, invites us to adopt - is precisely what enables us to bear this reality as it is despite it being unbearable, and in so doing to sustain this reality (Faÿ, 2008). Far from constituting a threat to the established order, this generalized contemporary cynicism is on the contrary the fetishistic supplement necessary for its maintenance. This figure of the cynic who is disdainful of the prevailing ideology, while acting like a perfectly obedient subject, can be well applied to the organization (Fleming and Spicer, 2003): managers who are disillusioned but hold their position, employees claiming to 'have a life outside of the job' to improve their employability (Cremin, 2010), human resources managers implementing severance plans while 'distancing themselves' from their role, researchers complaining about the effects of publication incentives while engaging in the publication race (Vidaillet, 2013b), etc. Not only does such a theoretical perspective call into question the notion that such detachment can actually threaten the models of organizational functioning, but it goes even further: it contributes to maintaining them (Richards and Kosmala, 2013).

Cynicism clearly shows that one does not need to believe in order to act (Žižek, 1989). This figure of the Cynic must be put into the broader context of the 'displaced ideological subject' (Fleming, 2010). Here, the displacement occurs from the subject's beliefs to the subject's practice: never mind the beliefs, it is through actions, practices, rituals, routines, and objects that the ideological devotion to the dominant order is maintained (Kosmala and Herrbach, 2006). There is a second kind of displacement: the displacement of the labor of belief onto supposed others. Even if these believing others might not 
exist, it is enough to presuppose that there are others who will believe for us in our place. This displacement of belief onto others involves a minimal belief in the belief of the other - even though this other does not, in actual fact, exist (Žižek, 1997). As Fleming (2010, p. 177) puts it: 'when I say 'I believe in the corporate culture', what I really mean is 'I believe there are some people who might believe in the corporate culture',

While cynicism, detachment or 'decaf resistance' merely reinforce the dominant order, other forms of resistance are found to be much more effective. This is exemplified by a work-to-rule action or 'flannelling' (Fleming and Sewell, 2002), which consists in implementing the law to the letter, causing a paralysis of the system, while at the same time making it difficult for the managers to respond since they are the ones who issued the orders and regulations. It also appears in actions such as 'believing too much' or 'over-identifying' with managerial discourse, which brings to the surface its inherent contradictions or ridiculous aspects (Fleming and Spicer, 2003; Hoedemaekers, 2009), or behaving in Bartleby fashion: stopping, preferring to 'not do' anything, to not succumb to the temptation of doing anything, to shake the foundations of the dominant ideology (Contu and Willmott, 2006; Fleming, 2010).

More generally, Lacan's theory sheds light on the dialectic between power and resistance in a particularly subtle manner. Indeed, fantasy serves to mask the fundamental lack in the symbolic order, which is the basis on which the subject's attachments and alienation operate. But because of the very structure of the symbolic order, the fundamental lack keeps reasserting itself. It is this structural impossibility in the symbolic order that explains the ultimate failure of power structures to fully determine the subjects: a space of freedom opens to them and enables them to resist (Jones and Spicer 2005; Laclau and Mouffe, 1985; Stavrakakis, 2008).

\section{Critique of the Capitalistic Organization: Jouissance, Object little a and Superego}

Another very useful Lacanian concept for the critical approaches to management and organizations is that of 'jouissance'. We have already presented it in the clinical section of this article but we shall now situate it in relation to other, equally important, Lacanian inventions, such as: 'the object little a'; Lacan's new theorization of the Freudian concept of superego; or his discourse theory.

While jouissance is what comes to substitute the irremediable loss of pre-symbolic (and fantasmatic) enjoyment that results from the child's introduction into the symbolic order (Lacan, 1969-70 / 2007), what is also lost in this process, is the representation of what the child was in the desire of the Other, which is what Lacan calls 'the object little a', the 'a' indicating how unrepresentable this object is. This object little a is what causes desire in the subject, hence the phrase 'the object-cause-of-desire'. 
Lacan will rename the 'object little a', 'surplus jouissance', in reference to the surplus value highlighted by Marx (Lacan, 1968-69 / 2002): the term is a synthesis of the idea of the initial irremediable loss of jouissance and of the consequence of this loss - which is to send the subject on a quest for surplus jouissance, in an endless repetition that haunts its life. On the whole, Lacanian researchers in MOS describe capitalism as the system that manages to operate the 'great reservoir' of libido by making it produce at full capacity. Governed by drive impulses, it is the expression of a single imperative: that of constant enjoyment which at once re-creates and destroys its object. The 'surplus jouissance' is the very lifeblood of capitalism: the principle behind surplus jouissance is precisely to hide the process by which the enjoyment is maintained through repetition, which is a symptom of its impossibility, but at the same time masks it.

These researchers pay particular attention to the subjective mechanisms that feed the frenzy of capitalism and place emphasis on the role played by the superego in this process. One of Lacan's (1972-73/1999) important theories is that the superego, in its most fundamental dimension, is much more a 'perverse' form of the law - which orders the subject to enjoy doing what s/he has to do - than the repressive force put forward by Freud. In this conception, the role of the law, of the symbolic authority is less repression in itself than to suppress the force of the compulsion to enjoy which the superego constitutes by hindering the subject's access to enjoyment, which is impossible anyway. Therefore, lifting the symbolic prohibition, instead of allowing access to a repressed enjoyment, leads on the contrary to releasing the superego's command to enjoy, which by definition is impossible to fulfill. Replacement of the symbolic Law with the superego then lays out the contours of a totalitarian universe: the subject is now subjected in its entirety to the law of the superego - the imperative of enjoyment/jouissance - which it can never satisfy whatever its efforts to obey it (McGowan, 2003). This results in it feeling permanently guilty that it 'doesn't manage' (to be happy, fulfilled, strong, etc.) and feeling exhausted from its constant attempts to meet the demand (Cederström, 2011). This conception is particularly useful for analyzing, from a critical perspective, the important place taken by coaching and personal development in contemporary firms, as well as the discourses relative to the quest for fulfillment and autonomy in the workplace (Owens, 2010), the rejection of the traditional forms of authority and power (Cederström and Grassman, 2010; Costas and Taheri, 2012), the identification to discourses that promise enjoyment through consumption and career success (Müller, 2013), or the frantic activism of those who work (Bloom, 2016; Bloom and Cederström, 2009; Cremin, 2010; Bicknell and Liefooghe, 2010). It is also helpful in analyzing the consequences of the evolution of global capitalism with globalized and financialised organizations in which it is difficult to identify a center of power: here, the disintegration of symbolic authority can cause employees to feel guilty for never doing enough to 'save' their factory from closing (Vidaillet and Gamot, 2015). 
Finally, let us mention one aspect of Lacanian theory that is tentatively used by researchers in MOS (String, 2006; Chemin-Bouzir and Contu, 2015; Costas and Taheri, 2012; Kosmala, 2013) but which is very useful when studying the relationship between subjectivity and capitalism, as has been clearly shown by certain researchers in the field of critical psychology and psychoanalysis (Bruno, 2010; Bryant, 2008; Pavón-Cuéllar, 2009; Tomšič, 2015; Vanheule, 2016). Lacan started pondering the notion of 'surplus jouissance' at a time when he was developing his four-discourse theory, to which he subsequently added the discourse of the capitalist. The 'problem' of language is that in speech, there can always be a shift in meaning since all meaning is expressed by signifiers that are always defined by other signifiers etc. Language, as we have seen, places the subject in the symbolic order while confronting it with the Real, since the symbolic order is always lacking. Discourse precisely helps to counter this shift in meaning by identifying places and linkages that do not need to be spoken to have meaning, but which articulate, in a particular manner, the symbolic order (the relation to the Other) and the Real. Lacan defines four discourses, that is to say, four types of stable linkages through which a subject can adjust its relation to the Other, to the Real and to jouissance. Discourses are the means through which subjects establish relations with each other and civilize jouissance. We will not discuss here those four discourses in detail; discourses which Lacan calls: the discourse of the Master, discourse of the University, discourse of the Hysteric and discourse of the Analyst (Lacan, 1969-70 / 2007). They all have in common that they take into account the division of the subject, an effect of language and of the relation of the subject to the Other, which involves an irreversible loss: the object little a - or object-cause-of-desire. They are also all constructed around a 'barrier to jouissance' which enables the subject to deal with jouissance by means of castration, upon which its inscription in the social link depends. But the capitalist discourse rejects castration, lack, and, by extension, masks the division of the subject; it is a discourse that removes the barrier to jouissance and presents itself as loss-less (in terms of jouissance) (Lacan, 1972/1978). The subject makes do without the Other, it does not have to rely on libidinal relations such as friendship, love or identification because jouissance does not lie with the Other; it remains bound to jouissance and is incapable of breaking from it: the loop of jouissance is like a closed circuit, indicating that the specificity of capitalism lies in its being an economics of jouissance (Bruno, 2010). In this respect, the capitalist discourse formalizes a way of functioning that is typical of our contemporary Western consumption culture. It is a discourse that does not encapsulate the discomfort of subjective division as structural, as a manifestation of subjective truth along the lines of the unconscious; on the contrary, it aims to propose answers for this discomfort (Pavón-Cuéllar, 2009). The latter is presented as resulting from the fact of not yet having obtained the right object, which suggests that a state of subjective satisfaction will be reached once this object is obtained. Capitalist discourse thus actively cultivates a fantasy of self-sufficiency and completeness (Tomšič, 2015), in which the market and the merchandise it provides hold the promise of putting an end to discontent. As pointed out by Vanheule (2016), 'the search associated with living with questions of existence ('who am I?' 'what do you want from me?') is replaced by a search for 
solutions in dealing with corporeal tension, and for experiences of fulfillment' (p.8-9). Whereas in the other four discourses, desire is singular in that it cannot be solved by means of the signifier, the capitalist discourse gives the illusion that desire might be treated as a question to be answered by means of practical solutions.

\section{Discussion and conclusion}

After introducing a paradigm shift (in the sense meant by Kuhn) into the psychoanalytic field - a shift which has served to rethink the theoretical, technical, therapeutic and ethical questions concerning his discipline - Lacan's ideas have in the last fifteen years made a remarkable break into MOS. As shown in the review of Lacanian research presented here, they have changed certain meanings that were commonly accepted, and have demonstrated how key Lacanian concepts such as the divided subject, the object little $a$, desire, jouissance, fantasy, or discourse as a social bond can be used productively to stimulate scientific imagination in this field.

An important contribution of our work is to show that Lacan-inspired organizational research is related to two orientations that refer to different academic areas: a clinical orientation, developed in reference to organizational psycho-dynamics; a critical orientation, which has imposed itself in the field of critical management studies. This relative disconnection is due more to the fact that it has been possible to use Lacan's work as an alternative to other theoretical currents within each field of study, than to a fundamental incompatibility between both orientations. They differ primarily in terms of the levels at which their analyses are conducted and in terms of the actions they propose. In the clinical approach, dysfunctions are analyzed at the level of the organization and of the subject's relation thereto. This approach considers that those dysfunctions can be dealt with through interventions implemented at local level and contingent on each case. Whereas in the critical approach, analysis of the dysfunctions and pathologies is structural and is situated within a broader critical framework, which concerns the capitalist system as a whole, including institutions, organizations and the subjects that operate it. The level of intervention advocated here is political. One consequence of these differences is that each of these two orientations has its own blind spot: Indeed, on the one hand, one of the limitations of clinical studies is that they tend to neglect political issues; and on the other, critical studies often fail to consider the singular unconscious dimension of the symptoms described, by mostly examining issues at a general level.

However, it must be stressed that this dichotomy does not apply to all the contributions we have reviewed. Indeed, some works we have examined encompass both orientations: i.e. the research conducted by Hoedemaekers (2010) and Hoedemaekers and Keegan (2010) on identity, that of 
Kosmala (2013) on the construction of discourses on competences, or the study conducted by Vidaillet and Gamot (2015) on the difficulties in exerting resistance in a typical global capitalist organization. These studies also show that Lacanian theory provides a theoretical framework that helps to link organizational psychoanalysis and CMS, two areas of study which are still ignorant of each other. There results from this framework a possibility to articulate the clinical to the critical, as Lacan's teachings have historically shown. Thus, on May 10, 1967, during his Seminar on 'The logic of fantasy', and referring explicitly to the announcement of a general strike in France and to the Vietnam War, Lacan made the now famous statement: 'the unconscious is politics'. He then immediately completed his statement by saying: 'What ties men together and what opposes them is precisely an aspect of what we are trying to articulate' (Lacan, 1966-67 / 2004: 360). He then subsequently pointed out and theorized the fact that the psychic and socio-political dimensions are two inextricable and opposite faces of the same phenomenon (Lacan, 1969-70/2007). Relatedly, the ultimate aim of Lacanian psychoanalytic treatment was never to 'heal' or 'cure' but to free the subjects from a state of helplessness, to enable them to rise and regain control over their own lives. This process can therefore also take on a collective dimension. It is in this regard that Lacan provides critical thinking with a political matrix rooted in clinical experience (Badiou, 1994-95 / 2013).

Another contribution of our review is to show that, regardless of the orientation - clinical or critical of the works examined here, they have in common that they draw support from Lacanian theory, which characterizes and distinguishes them from other works based on different approaches.

First, the language dimension, articulated to subjectivity, is essential to, and is present from the start, in Lacan's theory; making it possible to view both individual identity and social dynamics as being mediated by symbolic structures. Such is not the case for other post-Freudian schools (Kleinian, for example), who, through convoluted pathways, had to adapt concepts initially developed in a clinical context that paid no attention to language and discourse, to the field of organizational studies. Indeed, the Lacanian approach starts from the assumption that the unconscious is not linked to ineffable psycho-dynamic processes or drive-based forces, but to language and discourse (Lacan, 1957); the unconscious is considered as a discursive manifestation that has to do with the other. This conception is in line with Freud's characterization of the unconscious (Žižek, 1994) as 'trans-individual', or, in other words, as transcending the opposition between 'individual' and 'collective' unconscious; the unconscious is grounded in the transferential relationship towards the Other (Hook, 2008). Thus, the unconscious cannot be understood as a merely intra-psychic function, but as the outcome of the structural constraints within which a speech act occurs (Chiesa, 2007). It is therefore a nonpsychological perspective on the unconscious, which makes it possible, from the start, to situate the question of subjectivity within a wider social - or organizational - framework. 
Thus, Lacan considers that the status of the unconscious is more ethical than ontical (Neill, 2011), which is of interest from both the clinical and critical perspective. Indeed, the subjectivity in question here implies that one is always responsible for one's position as a desiring subject - which has consequences in terms of social and organizational functioning. Indeed, while the subject is an effect of the signifier, its responsibility is not to satisfy such or such a gaze (e.g. managerial, hierarchical, etc.) or to sacrifice oneself or offer oneself as an ideal (to the organization, market, union, etc.), but to account for the very effects of the laws of language. This, according to Lacan consists in accepting to own one's own speech (by recognizing that a linguistically structured unconscious determines the nature of the subject, to the extent that language escapes it) and in assuming responsibility for the fault that was blamed on the Other (Fink, 1995). Consequently, any subjective position whatsoever (including that of victim or of underdog) must also be seen as a choice the subject can account for and in so doing regain ownership of.

But this does not mean that 'management' is off the hook - in the sense that not everything is up to the subjects. Indeed, the latter can only account for the effects of the signifier in so far as their place is not confused with the locus of the signifier, and as the subjects can change through the act of speaking. For this purpose, they must therefore be allowed to speak in the organization, and so be given the opportunity to distance themselves from definitive, traumatic or alienating assignments, by operating their margin of freedom from professional signifiers supposed to represent them. This is what is facilitated by the discursive settings implemented or simply imagined by Lacanian researchers. A dialogue between the two orientations could then be envisaged with a view to testing joint clinical and critical methods of intervention.

A second anchor common to both clinical and critical works is the ontology of lack that characterizes the Lacanian perspective. Lacan was extremely critical of the clinical and theoretical approaches that promoted a developmental and corrective vision of mental health, and that considered as a legitimate and realistic aspiration the return of the patient to a well-integrated state of equilibrium and a normalized social functioning. Similarly, Lacan was suspicious of any discourse presenting accumulation, progress and growth as an ultimate goal of the socio-economic system and overstressing the importance of goals in terms of performance, gain, profit, credit, return on investment or dividend production. Lacanian theory is, on the contrary, a theory of lack, loss, cost, debt, waste, in which the possibility of gains and benefits is always intrinsically flawed and structurally dissatisfying (Nobus, 2013). This ontology which grants a central place to the Real and to the traumatic encounter of the subject with the Real is valuable for the clinical approach in that it enables the latter to deal in a radically new manner with a number of problems (related to motivation or identity for example) or to intervene differently. But it is also valuable for the critical approach when the researcher seeks to deconstruct the ideology on which the capitalist system is based. Furthermore, it provides the 
opportunity - as yet insufficiently exploited by researchers - to overcome the cleavage emphasized above between clinical and critical perspectives, by enabling researchers to envisage alternative organizations whose construction and operation take into account, from the onset, the dimensions of lack, loss, waste and incompleteness. In these respects, the insights contributed by the clinical orientation support the critical orientation in its ability to develop alternative ways of addressing the following issues (Glynos, 2010): What could those alternative models of organization and management, in line with the Lacanian conception of subjectivity, be like? How can the transition to those alternative models be managed? How and under what conditions can they develop?

Lacan's particular way of theorizing symptoms can be very useful here, although it has hitherto been little exploited by researchers in MOS. Most non-Lacanian approaches to organizational psychoanalysis consider that the latter's purpose is to uncover persistent unconscious phenomena that affect the rationality of organizational functioning, and to eliminate the symptoms that manifest them. In doing so, those approaches implicitly privilege a rational representation of the organization: the objective is to return to a form of rationality or to facilitate the emergence of 'another rationality' (that of another scene') and make it explicit. In the Lacanian approach, the symptom is considered to be a unique construction of the subject, a construction that must be handled in such a way as to preserve its uniqueness while minimizing or, if possible, eliminating its dimension of suffering or destructive potential. From an organizational perspective, the task is therefore to think of a way in which managerial systems can ensure that the singular dimension of desire that the symptom of each subject encompasses can be supported by the organization. The organizational ideal - if there is an ideal limits itself to allowing the circulation of desire and to avoiding promoting jouissance. No organized system can exist without friction, clashes, contradictions and dissensus; but it is because it is structured by lack that it can transform itself. The Lacanian approach excludes, from the onset, a stabilized organizational ideal, and insists instead on the dimensions of incompleteness, tension and permanent dynamic. At the critical level, this also means that no 'big night' - that would mark the emergence of a perfect system - is to be expected (no more than the emergence of a perfect Self) (Lacan, 1969-70/2007).

A third source of support shared by both orientations is related to the Lacanian conceptual trilogy of the Real, the Symbolic and the Imaginary. If one had to summarize the essence of Lacan's intellectual itinerary, three successive periods could, indeed, be distinguished, each corresponding to a focus on one of the three orders of human experience: the Imaginary (years 1930-1940: the period of the 'mirror stage'), the Symbolic (1950-60: the period of the theory of the signifier) and the Real (1970s: the period centered on the question of 'jouissance' and on the use of topology as a way of representing and conceptualizing the interdependence of the Real, the Symbolic and the Imaginary). Each of the two orientations, clinical and critical, draws differently from one or more of these three periods. Thus, 
it may appear at first glance that the clinical orientation feeds more on the early Lacan (that of the Imaginary and the Symbolic) and that the critical orientation draws more from the later Lacan (that of the Real). However, in reality, the three registers are mutually dependent and cannot operate without each other. Lacan himself had started early to conceptualize the Real-Imaginary-Symbolic triad as a complete paradigm for psychoanalysis, and had immediately stressed the importance of considering these three orders in their relation to each other (Lacan, 1953). It is therefore these inter-relations that have a structuring quality in both orientations studied.

Thus, in the clinical orientation, the Lacanian contribution to organizational psycho-dynamics, in which prevailed a separation between the Imaginary (unconscious) and reality, was to reconceptualize, differentiate and articulate the registers of the Imaginary (order of the ego) and of the Symbolic (order of the signifier), which is now differenciated from the Imaginary. This conceptual reshuffle has made it possible to identify the order of determination (or, on the contrary, the lack thereof) that previously eluded the analysis, and to refer it to the organizational symptoms studied and, if necessary, to resolve some problematic situations (Arnaud, 2003; Vidaillet, 2007; Vanheule and Arnaud, 2016). But that's not all. This differentiation of the Imaginary and the Symbolic is conducted, no longer in reference to external reality, but to the category of the Real, which corresponds to what the Symbolic expels when it establishes itself. Thus, while the Lacanian clinic of organizations is actually oriented by the differentiation between the Symbolic and the Imaginary, the Real is not to be denied. The place of the Real is determined in relation to the Symbolic, in that the former is unassimilable to the latter : whether indirectly as a horizon that escapes any symbolization (and therefore remains inaccessible to discursive settings such as coaching sessions, for example) (Arnaud, 2002); or as what constantly returns to the subject's experience because it is linked to the repetition of the quest for the lost object (such as the jouissance desperately sought for through professional stress) (Bicknell and Liefooghe, 2010).

In the critical orientation, another aspect of this Real is central to Lacanian researchers and enables them to make a distinctive contribution to CMS: the Real is also what refuses to 'function' and can come as a social symptom (Lacan, 1974/1975: 183). Thus, they can build on this category to explore how this symptom manifests itself at the organizational level and how they affect workers. This does not mean, however, that the Imaginary and the Symbolic are neglected. Indeed, the Real here refers to the notion of excess overflowing a symbolic order whose failure is masked by the Imaginary. The reason why Lacanian critical works seem to put greater emphasis on the Real is merely that it is central to the definition of the subject. Indeed, instead of representing an exteriority that would confirm the existence of a subjective interiority, the Real challenges the interaction between the interior and the exterior, and creates in the subject an intimate exteriority (an 'extimacy' as it has been 
referred to); The Real, as such, therefore participates in the determination of the subject in all that is external to the latter.

Beyond the obvious value of Lacanian theory for addressing organizational and social issues, two main pitfalls must be avoided. The first pitfalls has to do with the fact that, on the whole, regardless of the orientation - clinical or critical - Lacan is rightly regarded as a difficult author. The challenge is therefore to make his work more accessible, in a field in which, furthermore, there seems to be very little grasp of the psychoanalytic language in which it is written. While doing so, one must avoid the risk of reductionism or of using purely metaphorical concepts that are disconnected from the general theory (Arnaud and Vanheule, 2013). The second pitfall to avoid would be to assign psychoanalytic knowledge the function of constituting a Grand Theory of the Social (Frosh, 2010). Indeed, on the one hand, the question of knowing under which epistemological, ethical and methodological conditions this knowledge can be applied to nonclinical settings remains unanswered and calls for constant vigilance on the part of the researchers who use it (Kenny, 2009). It also requires of them a reflexivity through which they can remain aware of their own subjective position towards their research, by applying Lacan's teachings to themselves, so as to be able to recognize the lack around which they revolve at epistemological level and in their practice as researchers (Driver, 2007, 2016; Wozniak, 2010). On the other hand, there is a strong risk of considering psychoanalytic knowledge as an idealized form of knowledge, of developing psychoanalytic interpretations from the position of authority and implicit mastery and thus of turning the psychoanalytic discourse on the social world into a new 'master discourse' (Hook, 2008; Parker, 2008). Such a posture would be a betrayal of the teachings of Lacan who, in the clinical setting, encouraged psychoanalysts to ensure that their interpretative framework always remained open, and stressed the fact that psychoanalytic principles should be applied precisely against the discursive effects of truth and mastery (Fotaki and Harding, 2013).

One way to avoid developing such a master discourse would involve drawing directly from the organizational theory already present in Lacan's work. As underlined by Nobus (2013) or Vidaillet (2013c), most researchers who use Lacan as a basis for studying organizations are unaware that Lacan himself had a lifelong intellectual and personal interest in organizations. He invented a number of radical, proto-anarchist arrangements for running an organization, as the organization of his own school of psychoanalysis was a constant subject of concern for him - and in relation to this, the question of power, transmission, of the possibility of maintaining the desire of those who were affiliated to it as well as psychoanalysis' own requirement of truth. There is a desire in Lacan to think about the organizational consequences of the analytical discourse (Lacan, 1975), to prevent institutionalization, and avoid its inherent risks of 'deviations and compromises' (Lacan, 1980/2001, p. 317). Thus, his attempt to invent 'the pass' as a mechanism to select the 'school's analysts', the 
theorization and the implementation of the 'cartels', the dissolution by Lacan himself in 1980 of his school, denote an extreme concern for the way in which an organization can function. Consequently, 'a genuine appreciation of Lacan's contributions within the field of MOS should not proceed from a demonstration of the critical applicability of one or the other of his concepts to organizational life, but should start with a detailed analysis of the organizational theory that is already present and operative within Lacan's own work' (Nobus, 2013, p. 6-7).

Ultimately, our review shows that the introduction of Lacanian thought into MOS has had a revitalizing effect on both organizational psycho-dynamics and CMS, prompting a reflection on their respective limitations or potential deviations; namely, in the clinical field, strictly operational or even adaptive approaches, and in the critical field, abstract or very general analyses. A better interconnection between Lacan-inspired clinical and critical works could give rise to a "critique of the clinic', on the one hand (to restore the central role of the concept of power in the analysis of organizational dysfunctions), and a 'clinic of the critique', on the other hand (to remind that there are no general theoretical solutions to alienation in the workplace without considering subjective singularities). Such an interaction between the clinical and the critical will require new insights into Lacanian theory; indeed, much remains to be uncovered of Lacan's potential contribution to MOS.

\section{References}

Alvesson, M. \& Kärreman, D. (2000). Varieties of discourse: On the study of organizations through discourse analysis. Human Relations 53(9): 1125-1149.

Alvesson, M. \& Kärreman, D. (2011). Decolonializing discourse: Critical reflections on organizational discourse analysis. Human Relations 64(9): 1121-46.

Alvesson, M. \& Willmott, H. (2003). Studying management critically. London, Thousand Oaks, Calif.: Sage Publications.

Arnaud, G. (1998). The obscure object of demand in consultancy: A psychoanalytic perspective. Journal of Managerial Psychology, 13(7), 469-484.

Arnaud, G. (2002). The organization and the Symbolic: Organizational dynamics viewed from a Lacanian perspective. Human Relations, 55(6), 691-716.

Arnaud, G. (2003a). A coach or a couch? A Lacanian perspective on executive coaching and consulting, Human Relations, 56(9), 1131-1143.

Arnaud, G. (2003b). Money as signifier. A Lacanian insight into the monetary order. Free Associations, 10 Part 1 (53), 25-43.

Arnaud, G. (2007). Poweract and organizational work: Gérard Mendel's socio-psychoanalysis, Organization Studies. 28(3), 409-428.

Arnaud, G. (2012). The contribution of psychoanalysis to organization studies and management: An overview. Organization Studies, 33(9), 1121-1135.

Arnaud, G. (2013). Is there a desire for work ? Research in Management, Economics and Finance, 1: 15-19 (http://www.rimefi.com/Paper\%20Arnaud\%20Gilles.htm). 
Arnaud, G. \& Guinchard, R., (2008). A l'écoute du désir de travail. In R., Beaujolin, P., Louart \& M. Parlier. Le Travail, un Défi pour la GRH (236-252). Lyon: ANACT.

Arnaud, G. \& Vanheule, S. (2007). The division of the subject and the organization: A Lacanian approach to subjectivity at work. Journal of Organizational Change Management, 20(3), 359-369.

Arnaud, G. \& Vanheule, S. (2013). Lacanian psychoanalysis and management research: On the possibilities and limits of convergence. Management Decision, 51(8), 1664-1677.

Ashcraft, K., Kuhn, T. R. \& Coreen, F. (2009). Constitutional Amendments: "Materializing” Organizational Communication. Academy of Management Annals, 3(1): 1-64.

Badiou, A. (1994-95/2013). Lacan. L'Antiphilosophie 3. Séminaire 1994-1995. Paris: Fayard.

Badiou, A. \& Roudinesco, E. (2012). Jacques Lacan, Passé Présent. Paris: Le Seuil.

Bendl, R. (2008). Gender subtexts - Reproduction of exclusion in organizational discourse. British Journal of Management, 19, S50-S64.

Bicknell, M. \& Liefooghe, A. (2010). Enjoy your stress! Using Lacan to enrich transactional models of stress, Organization, 17(3), 317-330.

Bloom, P. (2016). Work as the contemporary limit of life: Capitalism, the death drive, and the lethal fantasy of 'work-life balance'. Organization, 23(4): 588-606.

Bloom, P. \& Cederström, C. (2009). 'The sky's the limit': Fantasy in the age of market rationality. Journal of Organizational Change Management, 22(2): 159-180.

Böhm, S. \& Batta, A. (2010). Just doing it: Enjoying commodity fetichism with Lacan. Organization, 17(3), 345-361.

Boxer, P. \& Palmer, B. (1994). Meeting the Challenge of the Case. In What makes consultancy work (358-371). London: South Bank University Press.

Bracher, M. (1996). Lacanian resources for organizational consulting. 13th Annual Meeting of the International Society for the Psychoanalytic Study of Organizations. New York, June.

Bruno, P. (2010). Lacan passeur de Marx. Paris: Erès

Bryant, L.R. (2008). Žižek's new universe of discourse: politics and the discourse of the capitalist. International Journal of .Žižek Studies. 2, 1-48.

Butler, N. (2008). Critical and clinical management studies. Ephemera, 8(1): 7-25.

Carr, A. (2002). Managing in a psychoanalytically informed manner: An overview. Journal of Managerial Psychology, 17, 343-347.

Carr, A., \& Gabriel, Y (2001). The psychodynamics of organizational change management: An overview. Journal of Organizational Change Management, 14, 415-421.

Cederström, C. (2011). Fit for everything: Health and the ideology of authenticity. Ephemera, 11(1). 27-45.

Cederström, C. \& Grassman, R. (2010). The unbearable weight of happiness. In Cederström, C. \& Hoedemaekers, C. (Eds). Lacan and Organization (101-132). London: MayFly.

Cederström, C. \& Hoedemaekers, C. (Eds) (2010). Lacan and Organization. London: MayFly.

Chaine, L. (2006). Big Other is telling you, 23rd Annual Meeting of the International Society for the Psychoanalytic Study of Organizations. Amsterdam/Haarlem, June.

Chemin-Bouzir, C. \& Contu, A. (2015). Towards critically performative management education. The Critical Management Studies Conference. Leicester, 8-10 June.

Chiesa, L. (2007). Subjectivity and Otherness: A Philosophical Reading of Lacan. Cambridge MA: Cambridge University Press. 
Contu, A. (2008). Decaf resistance. Management Communication Quarterly, 21(3). 364-379.

Contu, A. \& Willmott, H. (2005). You spin me round: The realist turn in organization and management studies. Journal of Management Studies, 42, 1645-1662.

Contu, A. \& Willmott, H. (2006). Studying practice: Situating talking about machine. Organization Studies, 27(12). 1769-1782.

Contu, A., Driver, M. \& Jones, C. (2010). Jacques Lacan with organization studies. Organization, 17(3). 307-315.

Costas, J. \& Taheri, A. (2012). The return of the primal father in postmodernity? A Lacanian analysis of authentic leadership. Organization Studies, 33(9). 1195-1216.

Cremin, C. (2007). Living and Really Living. Ephemera, 7(4): 526-542.

Cremin, C. (2010). Never employable enough: the (im)possibility of satisfying the boss's desire. Organization, 17, 131-149.

Dashtipour, P. (2009). Contested identities: Using Lacanian psychoanalysis to explore and develop social identity theory. Annual Review of Critical Psychology, 7: 320-337.

De Cock, C. \& Böhm, S. (2007). Liberalist fantasies: Žižek and the impossibility of the open society. Organization, 14(6). 815-836.

De Swarte, T. (2005). A Lacanian organizational perspective on a high tech company: The case of personnel assessment. Socio-Analysis, 7: 37-66.

Driver, M. (2003). Nothing clinical, just business? Reflections on psychoanalytically grounded organizational diagnosis and intervention. Human Relations, 56, 39-59.

Driver, M. (2005). From empty speech to full speech? Reconceptualizing spirituality in organizations based on a psychoanalytically-grounded understanding of the self. Human Relations, 58(9): 1091-110.

Driver, M. (2006). Beyond the stalemate of economics versus ethics: Corporate social responsability and the discourse of the organizational self. Journal of Business Ethics, 66, 337-356.

Driver, M. (2007). Reviewer feedback as discourse of the other. Journal of Management Inquiry, 16, 351-360.

Driver, M. (2008). New and useless: a psychoanalytic perspective on organizational creativity. Journal of Management Inquiry, 17, 187-197.

Driver, M. (2009a). Struggling with lack: A Lacanian perspective on organizational identity. Organization Studies, 30(1): 55-72.

Driver M. (2009b). From loss to lack: Stories of organizational change as encounters with failed fantasies of self, work and organization. Organization, 16(3): 353-369.

Driver, M. (2009c). Encountering the arugula leaf: The failure of the Imaginary and its implications for research on identity in organizations. Organization, 16(4): 487-504.

Driver, M. (2010). Learning as lack: Individual learning in organizations as an empowering encounter with failed imaginary constructions of the self. Management Learning, 41(5): 561-574.

Driver, M. (2013). The lack of power or the power of lack in leadership as a discursively constructed identity, Organization Studies, 34(3). 407-422.

Driver, M. (2014). The stressed subject: Lack, empowerment and liberation. Organization, 21(1): 90105.

Driver, M. (2015). How trust functions in the context of identity work. Human Relations, 68(6): 899923.

Driver, M. (2016). Making the absent subject present in organizational research. Human Relations, 69(3): 731-752. 
Driver, M. (2017). Motivation and identity: A psychoanalytic perspective on the turn to identity in motivation research. Human Relations, 70(5): 617-637.

Erkama, N. \& Vaara, E. (2010). Struggles over legitimacy in global organizational restructuring: A rhetorical perspective on legitimation strategies and dynamics in a shutdown case. Organization Studies, 31(7): 813-839.

Faÿ, E. (2008). Derision and management. Organization, 15(6). 831-850.

Fink, B. (1995). The Lacanian Subject, Princeton University Press, Princeton, NJ.

Fink, B. (2007). Fundamentals of Psychoanalytic Technique: A Lacanian Approach for Practitioners. New York: Norton.

Fleming, P., (2010). You Are Where You Are Not: Lacan and Ideology in Contemporary Workplaces. In Cederström, C. \& Hoedmaekers, C. (Eds). Lacan and Organization (169-186). London: MayFly.

Fleming, P. \& Sewell, G. (2002). Looking for The Good Soldier, Svejk: Alternative Modalities of Resistance in the Contemporary Workplace. Sociology, 36(4), 857-72.

Fleming, P. \& Spicer, A. (2003). Working at a cynical distance. Organization, 10(1), 157-179.

Fotaki, M. (2009). Maintaining the illusion of a free health care in post-socialism. Journal of Organizational Change Management, 22(2): 141-158.

Fotaki, M. (2010). Why do public policies fail so often? Exploring health policy-making as an imaginary and symbolic construction. Organization, 17(6), 703-720.

Fotaki, M. (2011). The sublime object of desire (for knowledge): Sexuality at work in business and management schools in England. British Journal of Management, 22, 42-53.

Fotaki, M., Böhm, S. \& Hassard J. (2010). The failure of transition. Journal of Organizational Change Management, 23: (6): 637-650.

Fotaki, M. \& Harding, N. (2013). Lacan and sexual difference in organization and management theory: Towards a hysterical academy? Organization, 20(2), 153-172.

Fotaki, M., Long, S. \& Schwartz, H. (2012). What can psychoanalysis offer organization studies today? Taking stock of current development and thinking about future directions. Organization Studies, 33(9), 1105-1120.

Foucault, M.. (1975/1977). Discipline and Punish. New York: Vintage.

Foucault, M.. (1976/1979). The History of Sexuality, Volume 1 : An Introduction. London: Allen Lane.

Foucault, M.. (1978-79/2008). The Birth of Biopolitics: Lectures at the Collège de France, 1978-1979. New York: Palgrave Macmillan.

Fournier V. \& Grey C. (2000). At the Critical Moment: Conditions and Prospects for Critical Management Studies. Human Relations, 53(1). 7-32.

Frosh, S. (2010). Psychoanalysis outside the clinic: Interventions in pychosocial studies, Basingstoke, Hants: Palgrave Macmillan.

Gabriel, Y. (Ed) (1999). Organizations in depth: The psychoanalysis of organizations. London: Sage.

Gabriel, Y. \& Carr, A. (2002). Organizations, management and psychoanalysis: An overview. Journal of Managerial Psychology, 17(5), 348-365.

Glynos, J. (2008). Ideological fantasy at work. Journal of Political Ideologies, 13(3): 275-296.

Glynos, J. (2010). Lacan at work. In Cederström, C. \& Hoedmaekers, C. (Eds). Lacan and Organization (13-58). London: MayFly.

Glynos, J. (2011). On the ideological and political significance of fantasy in the organization of work. Psychoanalysis, Culture \& Society, 16(4): 373-393. 
Glynos, J. \& Howarth, D. (2007). Logics of critical explanation in social and political theory. London: Routledge.

Glynos, J. \& Stavrakakis, Y. (2008). Lacan and political subjectivity. Subjectivity : International Journal of Critical Psychology. 24(1): 256-274.

Grant, D., Hardy, C., Oswick, C. \& Putnam, L. (Eds) (2004). The Sage handbook of organizational discourse. London: Sage.

Grey, C. (1994). Career as a project of the self and labour process discipline. Sociology, 28(2): 47998.

Guinchard, R. (1998). Absenteeism and phantasy. Journal of Managerial Psychology, 13(7): 485-497.

Guinchard, R. \& Arnaud, G. (2011). Psychanalyse du Lien au Travail - Le désir de travail. Paris: Elsevier Masson.

Harding, N. (2007). On Lacan and the becoming-ness of organizations/selves. Organization Studies, 28(11), 1761-1773.

Hardy, C., Lawrence, T. B. \& Grant, D. (2005). Discourse and Collaboration: The Role of Conversation and Collective Identity. Academy of Management Review, 30(1): 58-77.

Harley, B. \& Hardy, C. (2004). Firing blanks? An analysis of discursive struggle in HRM. Journal of Management Studies, 41(3): 377-400.

Hirschhorn, L. (1998). Beyond anxiety: Passion, flow and the psychodynamics of work. Paper presented at the 17th annual ISPSO symposium, Jerusalem, Israel.

Hirschhorn, L. \& Neumann, J. (1999). The challenge of integrating psychodynamic and organizational theory. Human Relations, 52(6), 683-692.

Hoedemaekers, C. (2009). Traversing the empty promise: Management, subjectivity and the Other's desire. Journal of Organizational Change Management, 22(2): 181 - 201.

Hoedemaekers, C. (2010). 'Not even semblance': Exploring the interruption of identification with Lacan. Organization, 17(3): 379-393.

Hoedemaekers, C. \& Keegan, A. (2010). Performance pinned down: studying subjectivity and the language of performance. Organization Studies, 31(8), 1021-1044.

Hook D. (2008) Articulating psychoanalysis and psychosocial studies: limitations and possibilities. Psychoanalysis, Culture \& Society, 13 (4). pp. 397-405.

Howarth, D., Norval, A. \& Stavrakakis, Y. (Eds) (2000). Discourse Theory and Political Analysis. Manchester: Manchester University Press.

Jadin, J-M. \& Ritter, M. (2012). La Jouissance au Fil de l'Enseignement de Lacan. Toulouse: érès.

Johnsen, R. \& Gudmand-Høyer, M. (2010). Lacan and the lack of humanity in HRM. Oganization, 17(3): 331-44.

Jones, C. (2010). Lacan in Organization Studies. In Cederström, C. \& Hoedmaekers, C. (Eds). Lacan and Organization (211-219). London: MayFly.

Jones, C. \& Spicer, A. (2005). The sublime object of entrepreneurship. Organization, 12(2), 223-246.

Kenny, K. (2009). Heeding the stains: Lacan and organizational change. Journal of Organizational Change Management, 22(2). 214-228.

Kenny, K. (2012). 'Someone big and important': Identification and affect in an international development organization. Organization Studies, 33(9): 1175-1193.

Kets de Vries, M. (Ed). (1991). Organizations on the Couch: Clinical Perspectives on Organizational Behavior and Change, San Francisco: Jossey-Bass. 
Kets de Vries, M. (2004). Organizations on the couch: A clinical perspective on organizational dynamics. European Management Journal, 22(2), 183-200.

Kets de Vries, M., \& Miller, D. (1984). The Neurotic Organization. San Francisco: Jossey-Bass.

Kets de Vries, M. \& Miller, D. (1987). Interpreting organizational texts. Journal of Management Studies, 24(3), 233-247.

Kosmala, K. (2013). Scripting shifts in the regulatory structures : Professional competence constructed as lack. Organization, 20(4): 577-595.

Kosmala, K. \& Herrbach, O. (2006). The ambivalence of professional identity: On cynicism and jouissance in audit firms. Human Relations, 59(10), 1393-1428.

Lacan, J. (1949/2006). The mirror stage as formative of the function of the I. In Écrits (75-81). New York: Norton.

Lacan, J. (1953/1982), « Le symbolique, l'imaginaire et le réel », conférence donnée à la Société Française de Psychanalyse le 8 juillet 1953, Bulletin de l'Association Freudienne, 1: 4-13.

Lacan, J. (1953-54/1988). Freud's Papers on Technique. The Seminar I. London, Norton.

Lacan, J. (1954-55/1988). The Ego in Freud's Theory and in the Technique of Psychoanalysis. The Seminar II. Cambridge, England: Cambridge University Press.

Lacan, J. (1955/2006). Variations on the standard treatment. In Écrits (269-302). New York: Norton.

Lacan, J. (1955-56/1993). The Psychoses. The Seminar III. London, Norton.

Lacan, J. (1956/2006). The function and field of speech and language in psychoanalysis. In Écrits (197-268). New York: Norton.

Lacan, J. (1957/2006). Seminar on “the Purloined Letter." In Écrits (11-48). New York: Norton.

Lacan, J. (1959-60/1992). The Ethics of Psychoanalysis. The Seminar VII. London, Norton.

Lacan, J. (1960/2006). The subversion of the subject and the dialectic of Desire in the Freudian unconscious. In Ecrits (671-702). London: Norton.

Lacan, J. (1963/2006). Kant with Sade. In Ecrits (645-668). London: Norton.

Lacan, J. (1964/1998). The Four Fundamental Concepts of Psychoanalysis. The Seminar XI. London: Norton.

Lacan, J. (1966/2006a). The subversion of the subject and the dialectic of Desire in the Freudian unconscious. In Ecrits (pp. 671-702). London: Norton.

Lacan, J. (1966/2006b). Seminar on ‘The Purloined Letter'. In Ecrits (pp. 6-48). London: Norton.

Lacan, J. (1966/2006c). The instance of the letter in the unconscious, or reason since Freud. In Ecrits (pp. 412-441). London: Norton.

Lacan, J. (1966/2006d). The function and field of speech and language in psychoanalysis. In Ecrits (197-268). London: Norton.

Lacan, J. (1966-67/2004), La Logique du Fantasme. Séminaire 1966-67. Paris: Editions de l'ALI, publication hors commerce.

Lacan, J. (1967/2001). Proposition du 9 octobre 1967 sur le psychanalyste de l'Ecole. In Autres Écrits (243-260). Paris: Le Seuil.

Lacan, J. (1968-69/2002). From an Other to the Other. The Seminar XVI. London: Karnac.

Lacan, J. (1969-70/2007). The Other Side of Psychoanalysis. The Seminar XVII. London: Norton.

Lacan, J. (1972/1978). Du discours psychanalytique. In Lacan in Italia 1953-1978. En Italie Lacan (pp. 32-55). Milan: La Salamandra. 
Lacan, J. (1972-73/1999). On Feminine Sexuality, the Limits of Love and Knowledge (Encore). The Seminar XX. London: Norton.

Lacan, J. (1974/1975), La Troisième. Intervention au Congrès de Rome du 31 octobre - 3 novembre 1974. Lettres de l'Ecole Freudienne, 16, novembre 1975: 177-203.

Lacan, J. (1975). Intervention au Congrès de l'EFP à la Grande Motte (2 November 1973). Les Lettres de l'Ecole Freudienne, 15, 69-80.

Lacan, J. (1980/2001). Lettre de dissolution. 5 janvier 1980. In Autres Ecrits. Paris: Le Seuil.

Laclau, E. (2004). Glimpsing the Future. In Critchley S. and Marchart O. (Eds). Laclau: A Critical Reader. London: Routledge.

Laclau, E. \& Mouffe, C. (1985). Hegemony and Socialist Strategy. London: Verso.

Leather, P. (1983). Desire: A structural model of motivation. Human Relations, 36(2): 109-122.

Lok, J. \& Willmott, H. (2014). Identities and Identifications in Organizations: Dynamics of Antipathy, Deadlock, and Alliance. Journal of Management Inquiry, 23(3), 215-30.

Long, S. (1991). The signifier and the group. Human Relations, 44(4), 389-401.

Long, S. (2006). Organizational defenses against anxiety: What has happened since the 1955 Jaques paper? International Journal of Applied Psychoanalytic Studies, 3, 279-295.

McGowan, T. (2003). The End of Dissatisfaction: Jacques Lacan and the Emerging Society of Enjoyment. New York: State University of New York Press.

McSwite, O.C. (1997). Legitimacy in Public Administration: A Discourse Analysis. New York: Sage.

Marchart, O. (2007). Post-Foundational Political Thought. Edinburgh: Edinburgh University Press.

Morgan, G. (1983). More on metaphor: Why we cannot control tropes in administrative science.

Administrative Science Quarterly, 28: 601-607.

Muller, M. (2013). Lack and jouissance in hegemonic discourse of identification with the state. Organization, 20, 279-298.

Mumby, D. K. \& Clair, R. P. (1997). Organizational discourse, in T. A. van Dijk, (Ed). Discourse Studies: A Multidisciplinary Introduction (181-205). London: Sage.

Naulleau, M. (2013). From the organizational Other to the managerial other. Re-Working Lacan at Work, ESCP Europe. Paris, June.

Neill, C. (2011). Lacanian Ethics and the Assumption of Subjectivity. Palgrave, London.

Nobus, D. (2000). Jacques Lacan and the Freudian Practice of Psychoanalysis. New York:

Routledge.

Nobus, D. (2013). Group spirit, work transference and dissolution: Lacan as an organizational theorist. Re-Working Lacan at Work, ESCP Europe. Paris, June.

Nobus, D. \& Quinn, M. (2005). Knowing Nothing, Staying Stupid: Elements for a Psychoanalytic Epistemology. Abingdon and New York, NY: Routledge.

Owens, C. (2010). Danger! Neurotics at work. In Cederström, C. \& Hoedmaekers, C. (Eds). Lacan and Organization (pp. 187-209). London: MayFly.

Parker, I. (1997). Discourse analysis and psychoanalysis. British Journal of Social Psychology, 36: 479-495.

Parker, I. (2008). Temptations of Pedagogery. Subjectivity 24, pp. 376-379.

Parker, I. (2011). Lacanian Psychoanalysis: Revolutions in Subjectivity. London and New York: Routledge. 
Parker, I. \& Pavón-Cuéllar, D. (Eds) (2014). Lacan, Discourse and Event: Psychoanalytic Approaches to Textual Indeterminacy. Hove: Routledge.

Pavón-Cuéllar, D. (2009). Marxisme Lacanien. Paris: Psychophores.

Pavón-Cuéllar, D. (2010). From the Conscious Interior to an Exterior Unconscious: Lacan, Discourse Analysis and Social Psychology. London: Karnac.

Pavón-Cuéllar, D. \& Parker, I. (2014). Introduction: Lacanian theory, discourse analysis and the question of the 'event'. In I. Parker and D. Pavón-Cuéllar (Eds), Lacan, Discourse and Event: Psychoanalytic Approaches to Textual Indeterminacy (1-14). Hove: Routledge.

Pratt, M. and Crosina, E. (2016). The nonconscious at work. The Annual Review of Organizational Psychology and Organizational Behavior, 3: 321-347.

Reed, M. (2004). Getting Real about organizational discourse, in D. Grant, C. Hardy, C. Oswick \& L. Putnam (Eds). The Sage Handbook of Organizational Discourse. London: Sage.

Reed, M. (2005). Reflections on the "Realist Turn" in Organization and Management Studies. Journal of Managament Studies, 42(8): 1621-44.

Richards, J., \& Kosmala, K. (2013). In the end, you can only slag people off for so long: Employee cynicism through work blogging. New Technology, Work and Employment, 28, 66-77.

Roberts, J. (2005). The power of the Imaginary in disciplinary processes. Organization, 12(5), 621645.

Schneider, S., \& Dunbar, R. (1992). A psychoanalytic reading of hostile takeover events. Academy of Management Review, 17, 537-567.

Scriver, S. \& Kenny, K. (2012). Dangerously Empty: Hegemony and the construction of the Irish entrepreneur, Organization, 19(5): 615-633.

Shepherdson, C. (2008). Lacan and the limits of language. New York: Fordham University Press.

Spicer, A. \& Fleming, P. (2007). Intervening in the inevitable: Globalization discourse in a public broadcaster. Organization, 14(4): 517-41.

Stavrakakis, Y. (2007). The Lacanian Left: Psychoanalysis, Theory, Politics, Edinburgh: Edinburgh University Press.

Stavrakakis, Y. (2008). Subjectivity and the organized Other: Between symbolic authority and fantasmatic enjoyment, Organization Studies, 29(7), 1037-1059.

Stavrakakis, Y. (2010). Symbolic authority, fantasmatic enjoyment and the spirits of capitalism: Genealogies of mutual engagement », in: Cederström, C. \& Hoedemaekers, C. (Eds), Lacan and Organization (59-100). MayFly: London.

Stein, M. (2000). After Eden: Envy and the defences against anxiety paradigm. Human Relations, 53, 193-211.

Styhre, A. (2008). Management control in bureaucratic and postbureaucratic organizations: A Lacanian perspective. Group and Organization Management, 33(6), 635-656.

Thomas, R., Sargent, L. D. \& Hardy, C. (2011). Managing organizational change: Negotiating meaning and power-resistance relations. Organization Science, 22(1): 22-41.Tomšič, S. (2015). The Capitalist Unconscious. Marx and Lacan. New York:Verso.

Tomšič, S. (2015). The Capitalist Unconscious. Marx and Lacan. London: Verso.

Torfing, J. (1999). New Theories of Discourse. Oxford: Blackwell.

Townley, B. (1993). Foucault, power/knowledge, and its relevance for human resource management. Academy of Management Review, 18(3): 518-45. 
Townley, B. (1994). Reframing Human Resource Management: Power, Ethics and the Subject at Work. London: Sage.

Vaara, E. \& Tienari J. (2008). A discursive perspective on legitimation strategies in MNCs. Academy of Management Review, 33/4: 985-993.

Vaara, E., Sorsa, V. \& Pälli, P. (2010). On the force potential of strategy texts: A critical discourse analysis of a strategic plan and its power effects in a city organization. Organization, 17(6): 685-702.

Vaara, E., Tienari, J. \& Säntti, R. (2003). The international match: Metaphors as vehicles of social identity-building in cross-border mergers. Human Relations, 53(4): 419-51.

Vanheule, S. (2016). Capitalist Discourse, Subjectivity and Lacanian Psychoanalysis. Frontiers in Psychology, 7 (December), 1-14.

Vanheule, S. \& Arnaud, G. (2016). Working with symbolic transference: A Lacanian perspective on executive coaching. Journal of Applied Behavioral Science. 52(3): 296-319.

Vanheule, S., Lievrouw, A., \& Verhaeghe, P. (2003). Burnout and intersubjectivity: A psychoanalytical study from a Lacanian perspective. Human Relations, 56(3), 321-339.

Vanheule, S., \& Verhaeghe, P. (2004). Powerlessness and impossibility in special education: A qualitative study on professional burnout from a Lacanian perspective. Human Relations, 57(4), 497519.

Vidaillet, B. (2007). Lacanian theory's contribution to the study of workplace envy. Human Relations, 60(11), 1669-1700.

Vidaillet, B. (2008a). Workplace envy. London: Palgrave McMillan.

Vidaillet, B. (2008b). Psychoanalytic contributions to understanding envy: classic and contemporary contributions. In R.H. Smith (Ed.). Envy: Theory and Research, Oxford University Press.

Vidaillet, B. (2013a). Fantasme et RSE. In Postel, N., \& Sobel, R. (Eds). Dictionnaire critique de la RSE. Lille: Presses Universitaires de Lille - Septentrion.

Vidaillet, B. (2013b). Evaluez-moi! Evaluation au travail: les ressorts d'une fascination, Paris: Le Seuil.

Vidaillet, B. (2013c). Review: Lacan and Organization. Organization, 20, 324-327.

Vidaillet, B. (2016). Envy, Schadenfreude and evaluation: Understanding the strange growing of individual performance appraisal. In Smith, R., Merlone, U. \& Duffy, M. (Eds). Envy at Work. New York: Oxford University Press.

Vidaillet, B. \& Gamot, G. (2015). Working and resisting when one's workplace is under threat of being shut down: A Lacanian perspective. Organization Studies, 36(8): 987-101.

Vidaillet, B., Vignon, C. (2010). Bringing back the subject into management education, Management Learning, 41(2). 221-241.

Westwood, R. I. \& Linstead, S. (2001). Language/organization: Introduction, in R. I. Westwood \& S. Linstead (Eds). The Language of Organization (1-19). London: Sage.

Wozniak, A. (2010). The dream that caused reality: The place of the Lacanian subject of science in the field of organization theory. Organization, 17(3), 395-411.

Žižek, S. (1989). The Sublime Object of Ideology. London: Verso.

Žižek, S. (1991). Looking Awry. An Introduction to Jacques Lacan through Popular Culture. Cambridge: MIT Press.

Žižek, S. (1994). The spectre of ideology. In Žižek, S. (ed.), Mapping Ideology. London \& New York: Verso, pp. 1-33.

Žižek, S. (1997). The supposed subjects of ideology. Critical Quarterly, 39(2), 39-59. 
Žižek, S. (2006). How to Read Lacan. London: Norton.

Žižek, S. (2009). Violence. London: Profile Books. 